\title{
The Influence of Quantum Learning Model on Students' Learning Activities in Social Studies Class
}

\author{
Anik Lutfiyah \\ Pascasarjana Program Studi Pendidikan Dasar \\ Universitas Negeri Surabaya \\ Surabaya, Indonesia \\ Aniklutfiyah1971@gmail.com
}

\begin{abstract}
The purpose of this research was to find out the influence of quantum learning model on elementary school students' learning activities in Social Studies class. This experimental research used Nonequivalent control group design. 34 students as the sample were not chosen at random. Data collection techniques used were observation and interview. Based on the observations and interviews that were obtained by using a model of quantum learning teaching the learning activity greatly increased. A summary of this study is the activity of the students in the social studies class is better.
\end{abstract}

Keywords—Quantum Teaching Model; Activity; conventional

\section{INTRODUCTION}

Learning activities are at the core of the learning process. This includes several components namely, materials, teachers, and learners. The third components are mutual linkages and interactions. Teachers have a very important role in learning. Therefore, teachers must have a lot of ways or models of learning. Learning activities are managed in these activities learners are active, fun, and significant. Thus, it will automatically affect the quality of teaching and learning activities. Quality in learning can be observed in terms of the learning process.

The learning process will be successful when at least a majority $(70 \%)$ of them were active in physical, spiritual, and social events, as well as revealing the desire, motivation, and confidence in learning that big, tall, and strong to enhance the activity of students in Social Science Learning prose (IPS) [1].

[2] Explains that "SOCIAL SCIENCE in elementary school has the meaning as the name of the fields of study that are linked from a number of concepts of social discipline, humanities, science, even the various issues and problems of social life". SOCIAL SCIENCE lesson in elementary school is centered on the development of the ability of learners in response to problems and social issues. IPS and lessons are lessons that tend to memorize. Therefore the role of a teacher is very necessary in the learning process.

A teacher can only be said to have done the learning activities if there is a change in behavior in the students as a result of such activities. This means that the learning process it gives impact to the development of the learners.
Based on the survey and the observation, the teacher in the study is not yet using appropriate learning model, students just listen, read, and work on a task. Therefore, one of the learning models that can be used when the learning takes place is a model of Quantum Learning Teaching (QT).

[3] changed the learning lively, with all feels, and include all necessary connection, interaction and the difference that maximize learning moments. Thus, Quantum Teaching suggests ways to become a better teacher [4]. Learning IPS could be improved by using a Quantum model of Teaching as a factor supporting the learning process.

[4] The analytical study based on the draft framework learning better known as TANDUR is subtitled as follows: (1) Grow i.e. interest and foster learning for the benefit of learners; (2) Natural, namely learners experiencing learning that creates experiences for students; (3) Name i.e. the students name the materials studied with keywords that attract; (4) providing an opportunity to Demonstrate the learners indicated that they knew about the material that has been studied; (5) Repeat i.e. repeats and affirms the learning that has been done by learners; and (6) i.e. give awards to Celebrate the learners over participation in learning.

In Quantum Learning Teaching learners are invited to learn everything starts from the immediate environment, from what they know. Then the teacher invites learners to expand his knowledge [5], so that the learners are easy to understand new knowledge presented by the teacher. By using Quantum Learning Teaching, learning becomes more meaningful for the students because the students are "experiencing" what is being studied and do not just view or memorize [6].

Examine the above description, then researchers do research in Social Science Learning in elementary school using Quantum Teaching model where by using the Quantum model of Teaching learners can be more active. This will facilitate learners to understand the subject matter being taught. In addition, Quantum model of Teaching will be able to facilitate teachers in the delivery of the subject matter.

This study uses two classes, namely control and experimental classes. The control class does not use the Quantum model of Teaching and experimental class uses the Quantum model of Teaching. So the influence of the use of Quantum model of Teaching on the acquisition of learning Social Science can be observed. 
Using the Quantum model of Teaching is expected to facilitate learners to understand the subject matter being taught especially at the IPS material so that it can improve the learning. In addition, by using the model of Quantum Teaching can enhance the liveliness of the learners in the following lessons learned during the learning process takes place. Quantum Teaching model in this study is a model of learning that are used during the learning process, IPS with associate all elements of the form sings class shouted, the skills of learners during a learning process, the ability learners in the holds and with all the liveliness of the learners.

\section{METHOD}

This research was carried out at SDN Wedoro, Waru, Sidoarjo Regency, sub district. Time observation executed in the first one year lesson 2017/2018. This research is a quantitative research, i.e. quasi-experiments with nonequivalent control group design. This design can be described as follows:

TABLE I. NONEQUIVALENT CONTROL GROUP DESIGN

$$
\begin{array}{lrr}
\mathrm{O} 1 & \mathrm{X} & \mathrm{O} 2 \\
\mathrm{O} 3 & \mathrm{O} 4
\end{array}
$$

Description:

$\mathrm{O} 1=$ before there was a treatment model Quantum Teaching

$\mathrm{O} 2=$ after there is a treatment model Quantum Teaching

$\mathrm{O} 3=$ before there was a treatment model Quantum Teaching

$\mathrm{O} 4=$ after there is a treatment model Quantum Teaching

$\mathrm{X}=$ Treatment model Quantum Teaching [7]

The subject of this research is the learners class IV SDN Wedoro i.e. class IVA as a control class with the number of 34 children and IVB as experimental class with the number of 34 children.

In this study there are two variables namely free or independent variable i.e. a model of quantum learning teaching and bound variable or dependent variable i.e. the activity.

The procedure performed in this study is divided into three stages, as follows.

\section{A. Preparation phase.}

The steps undertaken in this stage are: 1) carry out an observation. 2) determines the sample. 3) Designating classes of control and experimental classes. 4). 2) Prepare a learning device 4) Determine the material to be studied. 5) performs validation of the research instrument. 6) performs the test.

\section{B. Stages Of Implementation}

The steps undertaken in this stage are: 1) carry out a study with a control method of a class lecture and give treatment using quantum learning teaching model in class experiments.
2) carry out observations about the liveliness of the learners during a learning activity to take place.

\section{The Final Stage}

Here are the final stages:

1. Stages of Implementation

[8] The steps undertaken in this stage are: 1) carry out a study with a control method of a class lecture and give treatment using quantum learning teaching model in class experiments. 2) carry out observations about the liveliness of the learners during a learning activity to take place.

2. The Final Stage

In the final stages, it is to manipulate and analyze the data research results, and the conclusions of the data during the learning process.

Data collection techniques in the study are the technique of direct observation. For observation, it was done using observation sheets, in which researchers observed teachers during the IPS study.

The liveliness of the learners in the study was analyzed based on the average score of the implementation activities of learning.

This research uses techniques of observation data Gatherer. Observation is the technique of collecting data by way of holding observations on activities in progress at the time of the learning process. While the instrument used is the observation activity sheets and sheets observation learners learning quantum implementation of teaching. Instruments that have been made must be tested for validity and reliability, so that its data collection more complete results, systematic, and easily processed.

Research data observation activity analyzed average score of the implementation process of learners by using the following formula:

$\mathrm{P}=\mathrm{f} / \mathrm{N} \times 100 \%$

Description:

$\mathrm{P}=$ percentage off $=\mathrm{a}$ lot of activities that were carried out

$\mathrm{N}=$ number of totality activity was assessed. [9]

Assessment criteria the liveliness of the learners:

$$
\begin{aligned}
& 0 \%-19 \%=\text { very low } \\
& 20 \%-39 \%=\text { Low } \\
& 40 \%-59 \%=\text { moderate } \\
& 60 \%-79 \%=\text { high } \\
& 80 \%-100 \%=\text { very high }
\end{aligned}
$$

For the assessment of active participants is the only the description of the course.

\section{RESUlT AND DiscuSSION}

Based on the experience gained from the teacher who teaches at SDN Wedoro, [10] the learning process is done conventionally or using only lectures and assignments only difference. Learning with the use of lectures students will be active even less saturated and almost $90 \%$ of the participants learner less active, which in the end they play alone even tend to be sleepy. After he did the learning by using learning model quantum teaching [11] almost $85 \%$ of the students are very active. This can be known from the observation sheet activity 
the learners as assessment of physical, spiritual, and social. The learning process will be successful when at least a majority $(70 \%)$ of them were active in physical, spiritual, and social events, as well as revealing the desire, motivation, and confidence in learning that big, tall, and strong to enhance the activity of students in Social Science Learning process (IPS) [2] So it can be said that with the quantum learning model of teaching-learning activities can increase learners of class IV in the IPS material subjects cultural diversity.

\section{CONCLUSION}

Based on the results of data analysis on the influence of quantum learning model of teaching activity subjects IPS with the material cultural diversity has increased, and significant compared to learning accounting. It can be seen and it was determined by the results of the analysis that has been done. Learners are able to understand the material deeper.

\section{REFERENCES}

[1] R. M. Felder and L. K. Silverman, "Learning and teaching styles in engineering education," Engineering education, vol. 78, pp. 674-681, 1988

[2] D. Sapriya, "Pendidikan IPS," Bandung: PT. Remaja Rosdakarya, 2009.
[3] B. DePorter, Quantum teaching: PT Mizan Publika, 2000.

[4] B. DePorter, M. Reardon, and S. Singer-Nourie, Quantum teaching: mempraktikkan quantum learning di ruang-ruang kelas: Kaifa, 2010

[5] S. Hamid, J. Waycott, S. Kurnia, and S. Chang, "Understanding students' perceptions of the benefits of online social networking use for teaching and learning," The Internet and Higher Education, vol. 26, pp. $1-9,2015$.

[6] P. A. Kirschner, J. Sweller, and R. E. Clark, "Why minimal guidance during instruction does not work: An analysis of the failure of constructivist, discovery, problem-based, experiential, and inquiry-based teaching," Educational psychologist, vol. 41, pp. 75-86, 2006.

[7] Sugiyono, Metode penelitian pendidikan:(pendekatan kuantitatif, kualitatif dan R \& D): Alfabeta, 2008.

[8] J. D. Novak, Learning, creating, and using knowledge: Concept maps as facilitative tools in schools and corporations: Routledge, 2010.

[9] H. Warsito, "Pengantar Metodologi Pendidikan," Jakarta: Gramedia Pustaka, 1992.

[10] N. Asfaw, P. Licence, A. A. Novitskii, and M. Poliakoff, "Green chemistry in Ethiopia: the cleaner extraction of essential oils from Artemisia afra: a comparison of clean technology with conventional methodology," Green Chemistry, vol. 7, pp. 352-356, 2005.

[11] R. Rachmawati, "The Implementaton Quantum Teaching Method of Graduate Through Up-Grade Hard Skill and Soft Skill:(Case study on Management Accounting Class)," Procedia-Social and Behavioral Sciences, vol. 57, pp. 477-485, 2012. 